地域在住高齢者における超音波による

大腿部骨格筋評価と転倒経験の関連性

\title{
Relationship between evaluation of skeletal muscles of the Thigh region by ultrasonography and past falls in the community-dwelling elderly
}

\author{
杉田洋 介1 ${ }^{1)}$, 伊 藤 克 彦 ${ }^{2)}$
}

Yosuke Sugita ${ }^{1)}$, Katsuhiko Ito ${ }^{2)}$

\begin{abstract}
要旨：【目的】超音波による大腿部骨格筋評価と転倒経験との関連性を明らかにすること である。【方法】152名の地域在住高齢者を対象とした横断研究である。年齢, 性別, BMI, 運動機能，二重課題，注意機能，大腿部筋厚と筋輝度，等尺性膝伸展筋力を評価した。過 去 1 年間の転倒の有無を調查して, 二項ロジスティック回帰分析で転倒関連因子を抽出し た。【結果】開眼片脚立ち時間（オッズ比3.01）と Dual Task Timed Up and Go Test（オッ ズ比3.38）が転倒関連因子として抽出された。【結論】超音波で評価した大腿部骨格筋の 量的，質的指標は転倒経験に対しては独立した影響要因ではなかった。今回の結果からは, 自立歩行にて生活している地域在住高齢者においては, 立位姿勢保持能力ゃ二重課題遂行 機能が転倒経験に影響する要因である可能性が示唆された。
\end{abstract}

キーワード：転倒関連因子, 地域在住高齢者, 大腿部筋厚, 大腿部筋輝度

\begin{abstract}
Purpose】 The purpose of this study is to elucidate the relationship between falling and evaluation of skeletal muscles of the Thigh region by Ultrasonography. IMethods】 This is a cross-sectional study on 152 community-dwelling elderly individuals.Age, Gender,body mass index,motor function,dual task timed up and go test performance,attention function, Thigh muscle thickness and brightness,and isometric knee extension strength were evaluated.A binary logistic regression analysis was performed on the presence or absence of falls in the previous year surveyed to identify the factors associated with falls. 【Results】 One-leg standing with eyes opened test time (odds ratio 3.01) and the Dual Task Timed Up and Go Test (odds ratio 3.38) were identified as factors associated with falls. 【Conclusion】 None of the quantitative and qualitative factors of skeletal muscles of the Thigh region were identified to have an independent effect on the falls. These results suggested that the ability to maintain a standing position and dual task timed up and go test performance were potential factors of the risk of falls.
\end{abstract}

Key words: Fall-related factor, community-dwelling elderly, Thigh muscle thickness, Thigh muscle brightness

\footnotetext{
受付日：2017年10月 8 日, 採択日：2017年11月17日

1) 国立大学法人筑波技術大学：茨城県つくば市春日 4-12- 7 TEL：029-858-9568 e-mail :y.sugita@cc.k.tsukuba-tech.ac.jp National University Corporation Tsukuba University of Technology: 4-12-7 Kasuga, 21 Tsukuba-shi,Ibaraki 305-8521, Japan TEL:+81-29-858-9568

2) 国立病院機構埼玉病院

National Hospital Organization Saitama National Hospital
} 


\section{I 、はじめに}

高齢者が要介護状態に陷る要因の一つに，転倒が報 告されている1)。加齢とともに転倒リスクは上昇する こと ${ }^{2)}$, 転倒に伴う医療費・介護費用は年間 9,000 億円 を超えることが報告されている3゙。このような背景か ら，転倒リスク保有者を識別するためのスクリーニン グ指標や予防手段を確立することには意義がある。

高齢者の転倒には，等尺性膝伸展筋力など下肢筋力 低下に代表される身体機能低下 ${ }^{4)}$, 二重課題や注意機 能に代表される認知機能低下 ${ }^{5,6)}$, 主観的健康感や転倒 恐怖心などの心理的影響 27 など様々な要因が関連する。 これらの要因の中でも, 等尺性膝伸展筋力低下は転倒 に関連するオッズ比がもっとも高く，人種を問わず転 倒と関連することが報告されている ${ }^{8-10)}$ 。しかしなが ら, 筋生検や超音波で測定した筋線維数比率や断面積 と等尺性膝伸展筋力間には有意な相関関係がないこと が報告されている ${ }^{11)}$ 。また, 骨格筋内の脂肪や結合組 織などの非収縮組織は等尺性膝伸展筋力と負の相関を

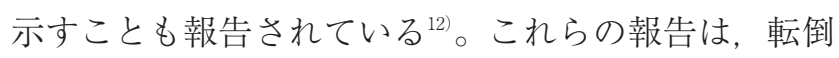
関連要因である等尺性膝伸展筋力が大腿部骨格筋量だ けで説明されるものではなく, 質的変化も含めて評価 することの必要性や質的変化が転倒関連指標となり得 る可能性を示唆しているが, この点についての検討は されていないのが現状である。

骨格筋の質的変化は, 超音波や核磁気共鳴画像法を 用いて測定される ${ }^{12,13)}$ 。超音波を用いて測定する際は, 筋輝度で評価されるが，筋輝度は筋生検で調べた筋内 脂肪・結合組織の割合と強い相関を示すことが報告さ れている ${ }^{14)}$ 。核磁気共鳴画像法を用いて測定する際に は, 筋断面積での評価となるが，断面積と等尺性膝伸 展筋力との相関係数は必ずしも高くないこと ${ }^{11)}$ や，断 面積の評価は非収縮組織も含有して算出されること ${ }^{15)}$, 時間的, 費用的負担がかかることから限られた施設で しか実施出来ないという現状課題もある。

このような先行研究の現状と骨格筋画像評価の実用 性課題を鑑みて, 本研究では地域在住高齢者を対象に, 超音波による骨格筋評価と転倒経験との関連性を明ら かにすることを目的に検討を行った。

\section{II. 対象と方法}

\section{1. 対 象 (表 1)}

研究対象は $\mathrm{A}$ 県 B市の2015年の特定健診および後期 高齢者健診該当者のうち，1）要介護認定を受けてお らず，2）自立歩行可能，3）本研究への参加に同意
した158名を研究期間中の登録者とした。追跡期間中 に死亡した 2 名, 入院加療となった 3 名, その他追跡 不可となった1名を除いた152名を分析対象者とした。 本研究はヘルシンキ宣言を尊重するように企画し, 研 究内容および公表の有無について書面にて同意を得た うえで進めた。全ての調查は筑波技術大学倫理審査委 員会の承認（H28－26）を得たうえで実施した。

\section{2. 研究デザイン}

研究デザインは横断研究とした。運動の一過性効果 や疲労の影響を除外するために，研究対象者には調査 実施前48時間以内での激しい身体活動や運動実施は避 けてもらった。また, 調査 3 時間前から絶食掞よびカ フェインの摂取を禁止とした。

\section{3 。転倒状況調查}

転倒は，「自分の意志からではなく，膝，上肢，あ るいは尻や腰などの身体部分が床面や地面などのより 低いレベルに接触すること」と定義した ${ }^{16)}$ 。妥当性と 信頼性を検討した先行研究 ${ }^{17.18}$ を参考に, 2 回以上の 転倒を転倒経験と定義して, 過去 1 年間の転倒経験の 有無を「ない」,「1 回だけある」,「2 回以上ある」の 3 件法にて聴取した。

\section{4. 大腿部筋厚ならびに筋輝度測定}

大腿部の筋厚ならびに筋輝度測定は, 超音波診断装 置（GEヘルスケア社製，LOGIQe）を使用し安静背 臥位に扮ける大腿直筋ならびに中間広筋の横断画像を 撮影した。超音波プローブはリニア型を用いて周波数 は $8 \mathrm{MHz}$, Gain53 (db), Cotrast6, Range4.0 (cm) に統一して設定した上で, 皮膚面に可能な限り圧力が 加わらないように配慮した。測定部位は上前腸骨棘と 膝蓋骨上縁を結んだ直線の中点として, 得られた横断 画像から大腿直筋と中間広筋の筋厚を合算して計測し た。また画像解析ソフト Image J (National Institute of Health, USA）を用いて, 大腿直筋と中間広筋の領 域に打ける筋輝度を Regions of interest（筋膜を除い た範囲）で 8 bit Gray-scale（ 0 -255）を用いて数值 化した。筋厚 - 筋輝度ともに 2 回計測し, その平均值 を用いた。

\section{5. 身体計測}

身体計測として身長, 体重を測定し, 体格指数 (Body Mass Index：BMI）を算出した。 


\section{6. 運動機能測定}

運動機能測定として開眼片脚立ち時間, $5 \mathrm{~m}$ 最速 歩行時間 ( $5 \mathrm{~m}$ Maximum Walking Test： 5 MWT), Timed Up and Go Test（TUGT)，30秒間椅子立ち上 がりテスト（30 second Chair-Stand Test：CS-30）を 実施した。開眼片脚立ち時間の測定は, 開眼で左右 2 回ずつ 120 秒を上限として測定し，その最長時間を秒 数換算で用いた。測定肢位は立位で，支持脚の膝を伸 ばし，挙げた脚は支持脚に触れないこと，支持脚の位 置がずれないことに注意し， $2 \mathrm{~m}$ 前方のマーカーを 注視する様に指示した。 $5 \mathrm{MWT}$ は， $1.5 \mathrm{~m}$ の加速路， $5 \mathrm{~m}$ の測定区間, $1.5 \mathrm{~m}$ の減速路からなる歩行路を設 置し，測定区間始まりの印を腰部または肩部が超えた 時点から，測定区間終わりの印を腰部または肩部が超 えるまでの所要時間を測定した。測定は 2 回実施し, 最速值を用いた。TUGTの測定は椅子座位から立ち 上がり, $3 \mathrm{~m}$ 先の目標物まで歩行し, 方向転換し元 の椅子の位置まで戻り着座するまでの時間を計測した。 測定は殿部が椅子から離れた時点から開始し, 殿部が 再び椅子に接地するまでの時間をデジタルストップ ウォッチで計測した。測定は 2 回実施し, 最速值を用 いた。CS-30の測定は高さ $40 \mathrm{~cm}$ の椅子を使用し，転 倒の危険が無いように検査者が配慮した。テスト開始 時の姿勢は，椅子に両下肢を肩幅程度に広げて座り， 背中を背もたれから離し，両腕は胸の前に組んだ姿勢 に統一した。測定は数回の練習の後に 1 回のみ行った。 30秒間にできるだけ多く，起立と着座動作を繰り返し， 起立位では股関節および膝関節が直立位となるように 指示した。

\section{7. 二重課題機能検査}

二重課題機能検査は, Dual Task Timed Up and Go Test（DT-TUGT）を用いた。DT-TUGTではTUG の遂行と同時に, 副課題として100から 3 を順次引く 暗算課題を声に出しながら行うよう指示した。DTTUGT 実施前には，座位にて50から減算する練習を 行った。さらにDT-TUGT 遂行にあたり，「歩くこと も計算することもどちらも可能な限り止めないでくだ さい」と, どちらか一方を優先させないことを研究対 象者に指示した。DT-TUGT 試行中に計算を間違えて も訂正を行わなかったが，足が止まっている，または 副課題に従事していない場合は試行を中止し 1 分間の 休鄎の後に再び実施した。

\section{8. 注意機能検査}

注意機能検査には Trail making test-Part A（TMTA）を用いた。紙面上にランダム配置された 1 から 25 までの数字を小さい方から順に線で結んでいく。評価 はスタートから順にすべてを結ぶまでの時間を測定し て，その所要時間を計測とした。

\section{9．等尺性膝伸展筋力測定}

等尺性膝伸展筋力の測定には，ハンドヘルドダイナ モメーター（アニマ社製，等尺性筋力計 $\mu \mathrm{Tas} F-1$ ) を用いて利き足にて測定した。端座位にて股関節屈曲 $90^{\circ}$ ，膝関節屈曲 $90^{\circ}$ の肢位にて行い、膝蓋骨下縁より 末梢 $20 \mathrm{~cm}$ の下腿前面に計測用パットを固定し，等尺 性膝伸展筋力を 3 回計測し，その平均值を用いた。

\section{0. 統計解析}

結果は平均土標準偏差で表記した。統計解析には SPSSver. 19（IBM 社製）を用いて有意水準 $5 \%$ 未満 にて解析を行った。群間比較は, 性別は $\chi 2$ 検定，大 腿部筋厚は Mann-Whitney U 検定，その他は 2 標本 $t$ 検定を行った。転倒に関連する要因を明らかにするた めに，転倒の有無を従属変数，年齢，BMI，開眼片脚 立ち時間，5 MWT, CS-30, TUGT, DT-TUGT, TMT-A， 大腿部筋厚，大腿部筋輝度，等尺性膝伸展 筋力を独立変数として二項ロジスティック回帰分析を 行った。独立変数の選択は多変量解析における Overfitting を避けるために，データを一切見ずに，先行研 究 ${ }^{199}$ を参考に，転倒に対する独立したリスク因子とし て報告されている項目を研究サンプル数の $1 / 10$ 項目 数となるよう選択した。オッズ比 $95 \%$ 信頼区間で検討 し, Pearsonの相関係数を求めることにより独立変数 間の多重共線性の確認を行った。また，適合性の検定 は Hosmer-Lemeshow の検定を用いて判断した。

\section{III. 結 果}

\section{1. 群間比較（表 1 ）}

研究対象とした152名中, 転倒経験者は26名，非転 倒経験者は126名（転倒発生率20.6\%）であった。2 群間での単変量解析結果で有意差を認めた項目は開眼 片脚立ち時間，CS-30，DT-TUGT，TMT-A，大腿部 筋厚, 大腿部筋輝度，等尺性膝伸展筋力であった。

\section{2. 二項ロジスティック回帰分析（表 2，3）}

二項ロジスティック回帰分析に先立ち, Pearsonの 
表 1 . 研究対象者の臨床的背景

\begin{tabular}{|c|c|c|}
\hline & \multicolumn{2}{|c|}{ Total $(n=152)$} \\
\hline & $\begin{array}{l}\text { Non-Fall-Group } \\
\quad(\mathrm{n}=126)\end{array}$ & $\begin{array}{c}\text { Fall-Group } \\
(\mathrm{n}=26)\end{array}$ \\
\hline 年齢 & $75.8 \pm 5.6$ & $76.3 \pm 4.5$ \\
\hline 性別（男女比） & $59 / 41$ & $17 / 15$ \\
\hline 身長（cm） & $153.7 \pm 9.1$ & $155.9 \pm 8.2$ \\
\hline 体重（cm） & $54.2 \pm 4.8$ & $56.1 \pm 6.9$ \\
\hline $\mathrm{BM} I \quad(\mathrm{~kg} / \mathrm{m} 2)$ & $23.1 \pm 2.1$ & $23.4 \pm 2.9$ \\
\hline 開眼片脚立ち時間（秒） & $9.8 \pm 2.7$ & $5.8 \pm 2.7^{* *}$ \\
\hline $5 \mathrm{MWT}$ (秒) & $5.1 \pm 0.8$ & $5.4 \pm 0.9$ \\
\hline CS-30（回） & $17.3 \pm 1.0$ & $16.2 \pm 1.2^{* *}$ \\
\hline TUGT（秒） & $10.2 \pm 0.6$ & $10.5 \pm 1.0$ \\
\hline DT-TUGT（秒） & $16.8 \pm 4.1$ & $20.2 \pm 4.2^{* *}$ \\
\hline TMT-A（秒） & $82.1 \pm 12.1$ & $76.5 \pm 4.7^{*}$ \\
\hline 大腿部筋厚（cm） & $3.3 \pm 0.3$ & $2.8 \pm 0.2^{* *}$ \\
\hline 大腿部筋輝度（\%） & $93.1 \pm 7.7$ & $98.6 \pm 6.1^{* *}$ \\
\hline 等尺性膝関節伸展筋力 $(\mathrm{Kgf} / \mathrm{kg})$ & $0.5 \pm 0.2$ & $0.4 \pm 0.1^{* *}$ \\
\hline \multicolumn{3}{|c|}{ 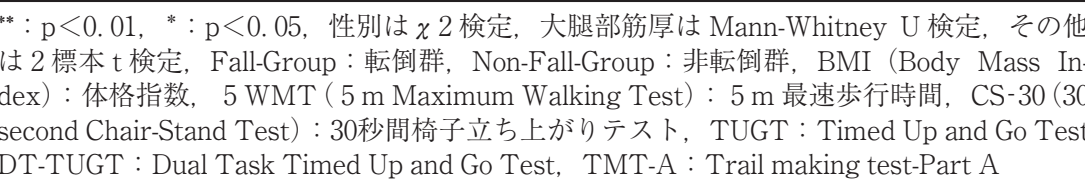 } \\
\hline
\end{tabular}

表 2. 独立変数間の相関係数

\begin{tabular}{|c|c|c|c|c|c|c|c|c|c|c|}
\hline & 年齢 & BMI & 開眼片脚立ち時間 & 5 MWT & $\mathrm{CS}-30$ & TUGT & DT-TUGT & TMT-A & 大腿部筋厚 & 大腿部筋輝度 \\
\hline 年齢 & & & & & & & & & & \\
\hline BMI & 0.075 & & & & & & & & & \\
\hline 開眼片脚立ち時間 & -0.164 & -0.096 & & & & & & & & \\
\hline $5 \mathrm{MWT}$ & 0.135 & -0.095 & $-0.641 * *$ & & & & & & & \\
\hline CS-30 & $-0.234^{* *}$ & 0.041 & $0.313^{* *}$ & $-0.430 * *$ & & & & & & \\
\hline TUGT & 0.063 & 0.068 & $-0.529 * *$ & $0.499 * *$ & $-0.651^{* *}$ & & & & & \\
\hline DT-TUGT & -0.088 & -0.081 & $-0.598 * *$ & $0.437 * *$ & $-0.526^{* *}$ & $0.519 * *$ & & & & \\
\hline TMT-A & -0.121 & -0.092 & $-0.487 * *$ & $0.412 * *$ & $-0.347 * *$ & $0.368 * *$ & $0.599 * *$ & & & \\
\hline 大腿部筋厚 & -0.090 & -0.076 & $0.391^{* *}$ & $-0.380 * *$ & $0.440 * *$ & $-0.353 * *$ & $0.543^{* *}$ & $0.412^{* *}$ & & \\
\hline 大腿部筋輝度 & -0.046 & -0.020 & $-0.199^{*}$ & 0.147 & $-0.208^{*}$ & $-0.280 * *$ & $-0.371^{* *}$ & $-0.298^{* *}$ & $-0.444^{* *}$ & \\
\hline 等尺性膝関節伸展筋力 & -0.062 & -0.022 & $0.352 * *$ & $-0.260 * *$ & $0.444^{* *}$ & $-0.274 * *$ & $0.476^{* *}$ & $-0.276^{* *}$ & $0.492 * *$ & $-0.558 * *$ \\
\hline
\end{tabular}

${ }^{* *}: \mathrm{p}<0.01,{ }^{*}: \mathrm{p}<0.05$, BMI (Body Mass Index)：体格指数， 5 WMT（ 5 m Maximum Walking Test）：5 m 最速歩行時間，CS-30（30second Chair-Stand Test) : 30秒間椅子立ち上がりテスト, TUGT : Timed Up and Go Test, DT-TUGT : Dual Task Timed Up and Go Test, TMT -A : Trail making test-Part A

相関係数により独立変数間の多重共線性の確認を行っ た結果, 相関係数が 0.8 たは 0.9 を超えるような変数 は存在しなかった。二項ロジスティック解析を行った 結果, 開眼片脚立ち時間（オッズ比3.01，95\%信頼区 間2.13-5.08）とDT-TUGT（オッズ比3. 38, 95\%信 頼区間2.98-5.42）が抽出された。

\section{IV. 考 察}

本研究では地域在住高齢者を対象に，超音波による
大腿部骨格筋評価と転倒経験との関連性を明らかにす ることを目的に横断的検討を行った。その結果, 開眼 片脚立ち時間と DT-TUGT が地域在住高齢者の転倒 発生関連因子として抽出された。その一方で，先行研 究で転倒との関連が報告されていた年齢や等尺性膝伸 展筋力,リサーチクエスチョンとして定めた大腿部筋 厚，筋輝度は転倒発生との間に関連を認めなかった。 年齢が関連因子とならなかった要因は, 対象者のリ クルーティング方法にあると思われる。本研究では, 
表 3 . 転倒経験の有無に対する二項ロジスティック回帰分析

\begin{tabular}{|c|c|c|}
\hline 独立変数 & オッズ比 & 95\%信頼区間 \\
\hline 年齢 & 1.14 & $0.81-1.12$ \\
\hline $\mathrm{BMI}(\mathrm{kg} / \mathrm{m} 2)$ & 0.98 & $0.93-1.08$ \\
\hline 開眼片脚立ち時間（秒） & 3. $01^{*}$ & $2.13-5.08$ \\
\hline $5 \mathrm{MWT}$ (秒) & 1. 34 & $0.76-2.01$ \\
\hline CS-30（回） & 2.12 & $0.99-5.66$ \\
\hline TUGT（秒） & 1.43 & $0.69-1.99$ \\
\hline DT-TUGT（秒） & 3. $38^{*}$ & $2.98-5.42$ \\
\hline TMT-A（秒） & 2. 01 & $0.97-3.21$ \\
\hline 大腿部筋厚 $(\mathrm{cm})$ & 2.34 & $0.91-5.53$ \\
\hline 大腿部筋輝度（\%） & 2. 66 & $0.61-16.12$ \\
\hline 等尺性膝関節伸展筋力 $(\mathrm{Kgf} / \mathrm{kg})$ & 2. 71 & $0.78-9.41$ \\
\hline
\end{tabular}

${ }^{*}: \mathrm{p}<0.05$, Hosemer-Lemeshow $の$ 検定 $: \mathrm{P}=0.917$, 判別的中率 93. 1\%, BMI（Body Mass Index）: 体格指数, 5 WMT（ 5 m Maximum Walking Test) : $5 \mathrm{~m}$ 最速歩行時間, CS-30 (30second ChairStand Test）：30秒間椅子立ち上がりテスト, TUGT：Timed Up and Go Test, DT-TUGT : Dual Task Timed Up and Go Test, TMT-A : Trail making test-Part A

特定健診および後期高齢者健診該当者のうち, 要介護 認定を受けていないこと, 自立歩行可能であることを 対象者の条件とした。しかしながら，特定健診からの 参加者は全体の 8 \%であったこと, 要介護認定者のう ち 80 代以上が $80 \%$ を占めていること ${ }^{20}$ から, 対象条件 である自立歩行可能かつ非要介護認定者は75歳～79歳 の対象者が大多数を占める結果となった。

等尺性膝伸展筋力は, 将来の転倒発生と関連するこ とが報告されている4)。しかしながら，自立歩行が可 能な高齢者の転倒は, 低い段差や電気コードなどに 引っかかったりすることが原因で発生すること ${ }^{211}$, ヒ トの平地歩行の際の足底と地面の差はわずかであり下 肢筋力に依存しないことなどから, 下肢筋力と転倒の 関連性よりも，立位姿勢保持能力が重要であるとの報 告がされている22.23)。これらの報告は等尺性膝伸展筋 力やそれに関連する大腿部筋厚, 筋輝度よりも開眼片 脚立ち時間が転倒発生と関連していた本研究結果を支 持する報告であると思われる。

DT-TUGT は転倒発生に独立して影響を与える要因 であった。近年では二重課題への対応能力の低下が, 高齢者の転倒発生と関連するとの報告が散見され $ろ^{5,24,25)}$ 。山田ら ${ }^{5)}$ は地域在住高齢者を対象に $10 \mathrm{~m}$ 歩行 時間と転倒との関連を調べた結果, 二重課題下での歩 行時間は転倒群が非転倒群と比較して延長しており, 二重課題での歩行時間が $38.8 \%$ 減速すると 6 か月以内 に転倒する確率が $84.8 \%$ になると報告している。この ように二重課題と転倒の関連については明らかであり， 本研究結果を支持する報告であると思われる。
本研究から得た知見としては, 地域在住高齢者にお ける検討において, 超音波で評価した大腿部骨格筋の 量的, 質的指標は転倒群・非転倒群間で有意に異なる 值を示したものの, 転倒発生に対しては独立した影響 要因ではなかった。自立歩行が可能で, 比較的活動性 が高い対象者にとっては，骨格筋量や下肢筋力よりも， つまずいたときに体を支えるだけの立位姿勢保持能力 や二重課題遂行機能などが, 転倒発生に影響する要因 である可能性が示唆された。

最後に本研究の限界を述べる。本研究結果は, 横断 調査による結果であるため, 転倒との因果関倸につい て言及することはできない。今後は縦断調査の結果を 基にした検討を実施して，骨格筋の量的，質的評価の 転倒に対する予測妥当性を検討していく必要がある。 また, 研究対象者について, 特定健診からの参加者が 少なかったこと, 大部分が後期高齢者健診受診者が研 究対象者となった経緯から選択バイアスが存在する。 加えて, 研究対象者が150名前後と疫学研究としては サンプルサイズが小さく第二種の過誤を生じている可 能性がある。今後は, より幅広い年齢層を対象とした 縦断的研究を行っていくことにより, これらの課題が 解決され，年代別の転倒関連因子が明らかにできるも のと思われる。

\section{引用文献}

1）厚生労働省 >平成27年国民生活基礎調査の概況> http://www.mhlw.go.jp/toukei/saikin/hw/k-tyosa/k-tyosa 13/dl/06.pdf>参照日2016-02-10.

2) Tinetti ME, Speechley M, Ginter SF: Risk factors for falls among elderly persons living in the community. N Engl J Med, 1988, 319(26): 1701-1707.

3）林泰史：転倒の医療経済に及ぼす影響. The Bone, 2009, 23 (2): $181-184$

4) Moreland JD, Richardson JA, Goldsmith $\mathrm{CH}$, et al.: Muscle weakness and falls in older adults: A systematic review and meta-analysis. J Am Geriatr Soc, 2004, 52(7): 1121-1129.

5）山田実, 上原稳章：二重課題条件下での歩行時間は転倒の 予測因子となりうる一地域在住高齢者を対象とした前向き 研究. 理学療法科学, 2007; 22:505-509.

6) Heilbronner RL, Henry GK, Buck P, et al.: Lateralized brain dam-age and performance on trail making $\mathrm{A}$ and $\mathrm{B}$, digit span forward and backward, and TPT memory and location. Arch Clin Neuropsychol, 1991, 6: 251-258.

7）村田伸, 津田彰：在宅障害高齢者の転倒と QOL との関連 健康支援, 2005, $7:$ 141-148.

8) American Geriatrics Society, British Geriatrics Society, American Academy of Orthopedic Surgeons Panel on Falls Prevention: Guideline for the prevention of falls in older 
persons. J Am Geriatr Soc, 2001, 49: 664-672.

9) Yamada M, Nishiguchi S, Fukutani N, et al.: Prevalence of sarcopenia in community-dwelling Japanese older adults. J Am Med Dir Assoc, 2013, 14(12): 911-915.

10) Landi F, Liperoti R, Russo A, et al.: Sarcopenia as a risk factor for falls in elderly individuals.Results from the ilSIRENTE study. Clin Nutr, 2012, 31(5): 652-658.

11）琉子友男, 福永哲夫：等尺性最大筋力に及ぼす筋断面積お よび筋線維組成の影響. 体力科学, 1986, 3 : 168-174.

12) Fukumoto Y, Ikezoe T, Yamada $Y$, et al.: Skeletal muscle quality assessed by echo intensity is associated with muscle strength of middle-aged and elderly persons. Eur J Appl Physiol, 2012, 112(4): 1519-1525.

13) Tamura $Y$, Tanaka $Y$, Sato F, et al.: Effects of diet and exercise on muscle and liver intracellular lipid contents and insulin sensitivity in type 2 diabetic patients. J clin Endocrinol Metab, 2005, 90(6): 3191-3196.

14) Pillen S, Tak RO, Zwarts MJ, et al.: Skeletal muscle ultrasound: correlation between fibrous tissue and echo intensity. Ultrasound Med Biol, 2009, 35(3): 443-446.

15）山田陽介：骨格筋量 - 筋力の評価法. 医道の日本, 2014, 248 (9) : 670-678.

16) Gibson MJ: Improving the health of older people: A World View. Oxford Univ. Press, New York, 1990, 269-315.

17) Nevitt MC, Cummings SR, Kidd S, et al.: Risk factors for recurrent nonsyncopal falls. A prospective study.JAMA, 1989, 261(18), 2663-2668.

18) Ganz DA, Higashi T, Rubenstein LZ, et al.: Monitoring falls in cohort studies of community-dwelling older people: effect of the recall interval. J Am Geriatr Soc, 2005, 53(12): 2190-2194.

19) Tinetti ME, Kumar C: The patient who falls: "it's always a trade-off". JAMA, 2010, 303(3): 258-266.

20）厚生労働省：介護保険事業状況報告（暫定）平成28年 9 月 http://www.mhlw.go.jp/topics/kaigo/osirase/jigyo/m16/ 1609.html.（参照日2017-10-20）

21）安村誠司, 芳賀博, 永井晴美, 他. : 地域の在宅高齢者に おける転倒発生率と転倒状況. 日本公衛誌, 1991；38：735 -742 .

22) Overstall PW, Exton-Smith AN, Imms FJ, et al.: Falls in the elderly related to postural imbalance. Br Med J, 1977; 1: 261 $-264$.

23) Lord SR, Clark RD, Webster IW, et al.: Physiological factors associated with falls in an elderly population.J Am Geriatr Soc, 1991; 39: 1194-1200.

24) Woollacott M, Shumway-Cook A: Attention and the control of posture and gait: a review of an emerging area of research. Gait Posture, 2002; Aug 16: 1-14.

25) de Hoon EW, Allum JH, Carpenter MG, et al.: Quantitative assessment of the stops walking while talking test in the elderly. Arch Phys Med Rehabil, 2003; 84: 838-842. 